\title{
DAKWAH KULTURAL DALAM TRADISI HILEYIA PADA MASYARAKAT KOTA GORONTALO
}

\section{CULTURAL DA'WAH OF HILEYIA TRADITION IN GORONTALO SOCIETY}

\author{
Erwin J. Thaib \\ Institut Agama Islam Negeri Sultan Amai \\ Jl. Gelatik No. 1 Gorontalo \\ Email: erwinthaib7578@gmail.com \\ Andries Kango \\ Institut Agama Islam Negeri Sultan Amai \\ Jl. Gelatik No. 1 Gorontalo \\ Email: erwinthaib7578@gmail.com
}

Naskah diterima tanggal 1 Januari 2018. Naskah direvisi tanggal 22 Februari 2018. Naskah disetujui tanggal 18 Mei 2018

\begin{abstract}
Abstrak
Studi ini mengungkap bagaimana realitas tradisi hileyia dalam masyarakat Kota Gorontalo, bagaimana wujud dakwah kultural dalam tradisi hileyia, serta apa efek dakwah kultural dalam tradisi hileyia pada masyarakat Kota Gorontalo. Pendekatan studi ini bersifat kualitatif yang mengungkap dakwah kultural dalam tradisi hileyia pada masyarakat Kota Gorontalo. Melalui studi ini digambarkan bagaimana dakwah disebarluaskan melalui medium budaya seperti tradisi hileyia. Dari hasil penelitian terungkap bahwa tradisi hileyia adalah suatu gambaran hubungan antara orang yang hidup dan yang sudah meninggal. Tradisi yang secara harfiah berarti pindah ini ditandai dengan berpindahnya seorang manusia dari dunia ini ke alam kubur karena sebab kematian. Hal ini diikuti dengan berpindahnya para keluarga dan kerabat dalam tempo tertentu ke rumah duka, beraktivitas secara bersama-sama yang diisi dengan doa arwah dan aktivitas kehidupan lainnya dengan tujuan untuk menghibur keluarga yang berduka. Tradisi hileyia dalam masyarakat Kota Gorontalo adalah sebuah tradisi yang memiliki nilai-nilai dakwah kultural. Hal ini diyakini karena tradisi hileyia mengandung pesan-pesan kebajikan yang bisa disebar luaskan melalui perantaraan tradisi ini. Dakwah kultural yang disebarluaskan melalui tradisi hileyia memiliki efek positif dalam masyarakat Kota Gorontalo. Efek positif ini antara lain kepedulian sosial, keikhlasan dalam berbagi, serta rasa persaudaraan yang tinggi. Efek sosial ini dipandang sebagai modal sosial (social capital) yang sangat berkontribusi dalam membangun harmoni sosial dalam masyarakat terlebih dalam konteks masyarakat Kota Gorontalo yang plural.
\end{abstract}

Kata kunci: dakwah, kultural, tradisi, Hileyia, Gorontalo

\begin{abstract}
:
This study explores how the reality of hileyia tradition in the society of Gorontalo city, how the form of cultural da'wah in hileyia tradition, and what the effect of cultural da'wah in hileyia tradition in the society of Gorontalo city. This study is qualitative research which reveals the cultural da'wah in hileyia in the society of Gorontalo city. The study describes how da'wah disseminated through cultural media such as hileyia tradition. The research result reveals that hileyia is a picture of the relationship between the living and the dead. Hileyia which means a move is characterized by the moving of a man from this world to the grave due to death. This is marked by the moving of families and relatives within a certain time to the home of bereaved family to do activities together as spiritual prayer and other life activities in order to entertain the bereaved family. Hileyia tradition in the society of Gorontalo city is a tradition which has values of cultural da'wah. It is believed because hileyia tradition contains right messages that can be disseminated through the intermediary of this tradition. Cultural da'wah which is disseminated through hileyia tradition has positive effects in the society of Gorontalo city. These positive effects include social awareness, sincerity in sharing, as
\end{abstract}


well as a high sense of brotherhood. This social effects is seen as a social capital that greatly contributes to building social harmony in society especially in the context of a plural society of Gorontalo city.

Keywords: da'wah, cultural,tradition, Hileyia, Gorontalo

\section{PENDAHULUAN}

I ntegrasi agama dan budaya merupakan realitas sosial yang terjadi di sebuah masyarakat. Ini dikarenakan kedua entitas memiliki posisi saling mempengaruhi yang disebabkan oleh nilai dan simbol. Agama memerlukan sistem simbol, dengan kata lain agama memerlukan budaya agama, tetapi keduanya perlu dibedakan secara hati-hati. Agama adalah sesuatu yang final, universal dan abadi, sementara budaya bersifat partikuler, relatif dan temporer. Agama tanpa kebudayaan dapat berkembang sebagai agama pribadi tetapi tanpa kebudayaan, agama sebagai kolektifitas tidak akan mendapatkan tempat (Kuntowijoyo, 1996:196).

Sebagai sebuah agama, Islam tidak terlepas dari kenyataan sejarah, yang mana di dalamnya terdapat kebudayaan yang saling mempengaruhi karena keduanya sarat nilai dan simbol. Agama adalah simbol yang melambangkan nilai ketaatan kepada Tuhan. Kebudayaan juga mengandung nilai dan simbol supaya manusia bisa hidup di dalamnya.

Interaksi dalam bentuk akulturasi, asimilasi ataupun sinkretisme antara agama dan kebudayaan itu dapat terjadi dengan, pertama; agama mempengaruhi kebudayaan dalam pembentukannya, nilainya adalah agama, tetapi simbolnya adalah kebudayaan. Kedua; agama dapat mempengaruhi simbol budaya. Sebagai contoh dalam hal ini adalah sistem pendidikan pesantren dan Kiainya yang memimpin pesantren tersebut sebagai bagian dari gagasan pendidikan Islam. Ketiga; kebudayaan dapat menggantikan sistem nilai dan simbol agama seperti yang terlihat dalam ritual upacara misalnya, upacara syukuran, pemberian nama bagi bayi yang baru lahir, upacara perkawinan maupun upacara kematian (Kuntowijoyo, 1996:198)

Islam yang dipraktikkan dalam kehidupan masyarakat Gorontalo, secara kasat mata adalah Islam yang tidak terpisahkan dari kehidupan kebudayaan mereka. Dengan kata lain, di mana Islam direalisasikan maka saat itu pula kebudayaan masyarakat hadir dengan berbagai bentuk dan variannya. Realisasi kehidupan budaya tersebut dinyatakan dalam berbagai ritual dan upacara. Lazimnya kehidupan kebudayaan dalam berbagai konteks masyarakat yang lainnya, masyarakat
Gorontalo juga mempraktikkan sisi-sisi kehidupan kebudayaannya, secara runut dan utuh. Kehidupan kebudayaan dimaksud terlihat dari peristiwa kelahiran bayi (menghadirkan ritual gunting rambut), ritual khitan/sunat, bae'at dan mandi lemon yaitu upacara peralihan dari anak-anak/ remaja menuju dewasa, ritual perkawinan, ritual raba-raba puru (upacara kehamilan pada bulan ke-7) dan upacara ritual hileyia, yaitu upacara ritual kematian. Semua ritual/upacara tersebut, berkaitan langsung dengan "diri manusia", yang juga dimaksudkan sebagai penegasan eksistensi kemanusiaan.

Kematian adalah sebuah keniscayaan dalam sejarah hidup manusia, bahkan seluruh mahluk hidup. Meskipun usianya lebih tua dari usia manusia itu sendiri, peristiwa matinya diri manusia akan selalu diratapi dan ditangisi oleh kerabat dan handaitaulannya yang masih hidup, kejadiannya menjadi sumber kesedihan yang mendalam. Peristiwanya mengandung nilai sakralitas yang cukup dalam, membuat manusia yang hidup, baik yang merupakan kerabat langsung maupun hanya sebagai orang-orang yang mengenalnya. Oleh karena itu beragam perilaku yang dilakukan oleh komunitas manusia untuk menyelenggarakan pengurusan kematian kerabatnya, baik yang berdasarkan pada agama maupun tata cara yang diwariskan oleh leluhur.

Berdasarkan hal tersebut, orang Gorontalo sebagimana masyarakat muslim lainnya, secara umum melaksanakan ritual kematian berdasarkan tata aturan Islam. Namun pada bagian-bagian tertentu dalam prosesi ritual itu, terdapat unsurunsur budaya lokal yang turut mewarnai upacara tersebut. Unsur-unsur budaya lokal juga banyak terlihat pada sisi simbol-simbol dari ritual upacara kematian yang sarat dengan maknanya yang dalam dan mewakili latar belakang mental-kognitif orang Gorontalo itu sendiri.

Pasca upacara ritual kematian setelah sang jenazah dikebumikan, keluarga dan handaitaulan yang masih dalam suasana duka melakukan ritual lain yang disebut hileyia, yaitu sebuah upacara ritual untuk mendoakan almarhum/ah yang dilakukan pada hari ke-1 hingga hari ke-7, kemudian dilanjutkan pada hari ke-10, ke-20, ke-30 dan puncaknya pada hari ke-40, yang merupakan 
puncak ritual hileyia sekaligus melakukan ritual "mopolahe paita" atau menurunkan batu nisan dan memasangnya di kubur almarhum/ah. Dalam ritual hileyia biasanya dilakukan dengan pembacaan zikir terutama tahlil (kalimat Laa Ilaaha Illallah), lalu membacakan doa-doa untuk almarhum/ah dan diakhiri dengan makan bersama. Sesungguhnya masih terdapat banyak hal yang berhubungan dengan ritual ini, terutama menyangkut simbolsimbol ritual yang digunakan, namun menurut penulis hal itu akan membawa "jauh" dari substansi penelitian ini sehingga dihindari untuk membahasnya.

Pada tahapan ritual hileyia inilah penulis menduga terdapat banyak hal yang merupakan praktik dakwah kultural terhadap orang-orang yang ditinggalkan almarhum/ah. Sebagai gambaran sederhana bahwa dakwah kultural adalah dakwah yang bersifat akomodatif terhadap nilai budaya tertentu secara inovatif dan kreatif tanpa menghilangkan aspek substansial keagamaan. Dapat diamati, mulai dari bacaan zikir dan doa, kehadiran para keluarga/tetangga/handaitaulan, makanan yang dihidangkan maupun suasana silaturahim yang ditimbulkannya pada ritual tersebut, semua kental akan dakwah kultural. Dengan dasar inilah maka perlu dilakukan kajian tentang "Dakwah Kultural Dalam Tradisi Hileyia Pada Masyarakat Kota Gorontalo."

Isu pokok yang diungkap dalam artikel ini adalah bagaimana realitas tradisi hileyia dalam masyarakat Kota Gorontalo, bagaimana wujud dakwah kultural dalam tradisi hileyia, serta apa efek dakwah kultural dalam tradisi hileyia pada masyarakat Kota Gorontalo.

Artikel ini bertujuan untuk mengetahui bagaimana realitas tradisi hileyia pada masyarakat Kota Gorontalo, nilai-nilai dakwah kultural yang terkandung di dalamnya, serta apa efek tradisi ini bagi kehidupan sosial masyarakat Kota Gorontalo.

Metode penelitian yang digunakan adalah kualitatif, yakni penelitian yang dimaksudkan untuk memahami fenomena tentang apa yang dialami oleh subjek penelitian menghasilkan data deskriptif berupa kata-kata yang tertulis atau lisan dari orangorang dan perilaku yang diamati (Moleong, 1991:6). Oleh karena itu, dapat dikatakan bahwa penelitian ini bersifat deskriptif kualitatif. Artinya, penulis menganalisis dan menggambarkan penelitian secara objektif dan mendetil untuk mendapatkan hasil yang akurat.Secara teoretis, penelitian deskriptif adalah penelitian yang bermaksud untuk mengumpulkan informasi mengenai status suatu gejala yang ada, yaitu keadaan gejala menurut apa adanya pada saat penelitian dilakukan, sehingga hanya merupakan penyingkapan fakta dengan menganalisis data (Arikunto, 2007: 234). Dengan metode ini maka penelitian ini berupaya menemukan data kongkrit tentang bagaimana tradisi hileyia dilaksanakan dalam masyarakat Kota Gorontalo. Pengumpulan data dilakukan melalui wawancara dan studi dokumentasi. Observasi penelitian dilakukan dengan ikut berpartisipasi dalam pelaksanaan tradisi hileyia.

\section{Tinjauan Pustaka \\ Konsepsi Dakwah Kultural}

Dakwah kultural adalah metode yang digunakan untuk menanamkan nilai-nilai Islam dalam seluruh dimensi kehidupan dengan memperhatikan potensi dan kecenderungan manusia sebagai makhluk budaya secara luas, dalam rangka mewujudkan masyarakat Islam yang sebenarnya.

Dalam konsep dakwah kultural, seorang dai berusaha memahami potensi dan kecenderungan manusia sebagai mahluk yang berbudaya, yang berarti memahami ide-ide, adat istiadat, kebiasaan, nilai-nilai, norma, sistem aktivitas, simbol dan halhal fisik yang memiliki makna tertentu dan hidup subur dalam kebiasaan masyarakat. Pemahaman tersebut dibingkai oleh pandangan dan sistem nilai ajaran Islam yang membawa pesan "Rahmatan lil 'alamin". Dengan redaksi lain bahwa dakwah kultural menekankan pada dinamisasi dakwah, yang artinya mencoba untuk mengapresiasi menghargai potensi dan kecenderungan manusia sebagai mahluk dalam arti luas, sekaligus melakukan usaha-usaha agar budaya tersebut membawa pada kemajuan dan pencerahan hidup manusia, selain hal-hal yang purifikasi. Karena itu dakwah kultural bukan berarti melestarikan atau membenarkan hal-hal yang bersifat takhayul dan khurafat, tetapi cara memahami dan menyikapinya dengan menggunakan kaca mata atau pendekatan dakwah islami.

Selanjutnya, potensi manusia dalam melahirkan kebudayaan digunakan sebagai media untuk memahami pesan dakwah (ajaran Islam) yang terdapat dalam tataran empiris atau pesan dakwah tersebut tampil dalam bentuk pengamalan formal yang menggejala di masyarakat. Pengamalan ajaran Islam yang terdapat di masyarakat tersebut diproses oleh penganutnya dari sumber ajaran aslinya 
sehingga ajaran Islam menjadi membudaya di kalangan masyarakat. Selain itu, pengamalan ajaran Islam tidak lepas dari memperhatikan kebudayaan yang berkembang di masyarakat, yakni dengan melalui pemahaman terhadap budaya, seorang akan dapat mengamalkan ajaran Islam itu sendiri sebagai proses adaptasi. Hal ini membuktikan bahwa ajaran Islam yang Rahmatan lil 'a $>$ lami $>\mathrm{n}$ yang bersifat universal dapat berlangsung dimanapun dan kapanpun ia berada.

Oleh karena itu, dakwah kultural adalah salah satu cara berdakwah yang menggunakan pendekatan budaya, yaitu; pertama, dakwah yang bersifat akomodatif terhadap nilai budaya tertentu secara kreatif dan inovatif tanpa menghilangkan aspek substansial keagamaan. Kedua, menekankan pentingnya kearifan dalam memahami kebudayaan komunitas tertentu sebagai obyek atau sasaran dakwah. Jadi, dakwah kultural merupakan dakwah ang bersifat bottom up, yang melakukan pemberdayaan kehidupan beragama berdasarkan nilai-nilai spesifik yang dimiliki oleh mad'u secara komunal (Ramdani, 2016: 169).

Dengan demikian, relasi dakwah dan budaya lokal tampak erat dalam bentuknya yang resiprokal, sinergis dan kohesif. Keduanya saling mendukung eksistensi masing-masing. Budaya lokal mendukung berlangsungnya keberhasilan dakwah dan dakwah sendiri mendukung keberlangsungan dan kelestarian budaya lokal.

Dakwah kultural adalah aktivitas dakwah yang menekankan pendekatan Islam kultural. Islam kultural adalah salah satu pendekatan yang berusaha meninjau kembali kaitan doktrin yang formal antara Islam dan politk atau Islam dan negara (Sulthon, 2003: 34). Dakwah kultural hadir untuk mengukuhkan kearifan-kearifan lokal yang ada pada suatu pola budaya tertentu dengan cara memisahkannya dari unsur-unsur yang bertentangan dengan nilai-nilai ajaran Islam. Dakwah kultural tidak menganggap power politik sebagai satu-satunya alat perjuangan dakwah. Dakwah kultural menjelaskan, bahwa dakwah itu sejatinya adalah membawa masyarakat agar mengenal kebaikan universal, kebaikan yang diakui oleh semua manusia tanpa mengenal batas ruang dan waktu.

Dakwah kultural memiliki peran yang sangat penting dalam kelanjutan misi Islam di Bumi ini. Suatu peran yang tak diwarisi Islam Politik atau struktural yang hanya mengejar kekuasaan yang instan. Oleh karena itu, dakwah kultural harus tetap ada hingga akhir zaman. Menurut Prof. Dr.
Said Aqil Siradj, M.A., jika dilihat secara hiostoris dakwah kultural sudah ada sejak zaman Muawiyah yang dipelopori oleh Hasan Bashri (w. $110 \mathrm{H}$ ) yaitu dengan mendirikan forum kajian yang nantinya melahirkan para ilmuwan dari berbagai disiplin ilmu, hingga kemudian diteruskan oleh para Walisongo, KH. Hasyim Asy'ari, KH. Ahmad dahlan dan lain sebagainya (Siradj, 1999:35).

Dalam permainannya yang dimainkan oleh cendekiawan Muslim, dakwah kultural mempunyai dua fungsi utama yaitu fungsi ke atas dan fungsi ke bawah. Dalam fungsinya ke lapisan atas antara lain adalah tindakan dakwah yang mengartikulasikan aspirasi rakyat (umat muslim) terhadap kekuasaan. Fungsi ini untuk mengekspresikan aspirasi rakyat yang tidak mampu mereka ekspresikan sendiri dan karena ketidak mampuan parlemter untuk mengartikulasi aspirai rakyat. Fungsi ini berbeda dengan pola dakwah struktural karena pada fungsi ini lebih menekankan pada tersalurkannya aspirasi masyarakat bawah pada kalangan penentu kebijakan.

Sedangkan fungsi dakwah kultural yang bersifat ke bawah adalah penyelenggaraan dakwah dalam bentuk penerjemahan ide-ide intelektual tingkat atas bagi umat muslim serta rakyat umumnya untuk membawakan transformasi sosial. Hal yang paling utama dalam fungsi ini adalah penerjemahan sumber-sumber agama (Al-Quran dan Sunnah) sebagai way of life. Fungsi dakwah kultural ini bernilai praktis dan mengambil bentuk utama dakwah bil hal (Amin, 2009:166).

Dalam penyampaiannya, dakwah kultural sangat mengedepankan penanaman nilai, kesadaran, kepahaman ideologi dari sasaran dakwah. Dakwah kultural melibatkan kajian antara disiplin ilmu dalam rangka meningkatkan serta memberdayakan masyarakat. Aktivitas dakwah kultural meliputi seluruh aspek kehidupan, baik yang menyangkut aspek sosial budaya, pendidikan, ekonomi, kesehatan, alam sekitar dan lain sebagainya. Keberhasilan dakwah kultural ditandai dengan teraktualisasikan dan terfungsikannya nilainilai Islam dalam kehidupan pribadi, rumah tangga kelompok, dan masyarakat.

\section{Hileyia, Budaya Agama dalam Masyarakat Gorontalo}

Hileyia adalah suatu kegiatan sosial dalam rangka kedukaan. Arti kata hileyia yaitu pemindahan kegiatan sosial yang berasal dari rumah para tetangga kepada rumah yang berduka, 
seperti memindahkan dapur tetangga, ke rumah yang berduka agar di rumah tersebut ramai dan yang berduka terhibur. Hal ini merupakan bantuan sosial kemanusiaan karena kondisi yang berduka belum konsen dan memperhatikan persoalan makan dan minumnya. Dengan memasak beramairamai di rumah kedukaan, merupakan ta'ziah Dulialo kepada keluarga yang berduka, di samping membantunya dengan bahan makanan.(Daulima, 2017: 195)

Hileyia dalam praktiknya juga dipahami oleh orang Gorontalo sebagai doa kepada arwah/ruh keluarga yang telah meninggal. Dilakukan mulai pada hari ke-1 hingga ke-7 secara terus menerus, lalu hari ke-10, ke-20, ke-30, ke-40, ke-100 dan ke300. Setelah hari ke-300 diperingati sebagai haul atau peringatan setahunan yang dalam istilah lokal disebut dengan "mongaruwa", diperingati setiap tahun sejak hari meninggalnya. Pada praktik, hileyia secara substantive adalah pembacaan beberapa surat dalam Alquran, kemudian pembacaan tahlil dan pembacaan doa keselamatan untuk mayit yang telah meninggal.

Dalam tradisi hileyia di Gorontalo, tata urutan bacaan telah diatur sedemikian rupa. Adapun urutan bacaan tahlil dalam ritual hileyia adalah;

a. Niat tahlil untuk si mayit,

b. Membaca Surat Al-Fatihah,

c. Membaca Surat Al-Ikhlas, Al-Falaq, An-Nas,

d. Membaca Surat Al Fatihah (lagi),

e. Membaca 6 ayat awal Surat Al-Baqarah,

f. Membaca Ayat Kursi,

g. Membaca Surat Al-Baqarah 4 ayat terakhir,

h. Membaca Shalawat dan Istighfar,

i. Membaca tahlil 100x atau 300x,

j. Membaca doa untuk mayit,

k. Makan (makanannya sesuai ketentuan adat).

Adapun sajian wajib yang merupakan hidangan yang tidak terpisahkan dengan lafadz doa yang diucapkan sebagai simbol doa yang dihidangkan dan dicicipi, meliputi:

a. Nasi kuning,

b. Bajo'e (Wajik/nasi ketan),

c. Pisang,

d. Telur,

e. Makanan tambahan sebagai pelengkap,

f. Dilengkapi alat perlengkapan ritual doa, yaitu; bara api, kemenyan, dan segelas air (Daulima, 2017: 198-199).

Pada akhirnya bahwa tataran realitas keberagamaan orang Gorontalo dalam tradisi hileyia serta keseluruhan proses ritual yang melingkupinya, sebagai perwujudan dari refleksi perpaduan Islam dan budaya lokal dalam konteks etnik Gorontalo, adalah hal yang niscaya. Keniscayaan tersebut terletak pada falsafah orang Gorontalo, "adati hulahula'a to syara'a, syara'a hula-hula'a to quru'ani (adat bersendi syara,', syara' bersendi Alquran).

\section{Realitas Tradisi Hileyia pada Masyarakat Kota Gorontalo Makna Hileyia}

Masyarakat Gorontalo adalah suatu kelompok masyarakat yang hidup dengan ikatan budaya dan tradisi yang terus bertahan hingga hari ini. Gorontalo memiliki beragam tradisi yang melekat dalam berbagai segi kehidupan dan dapat ditemui di seluruh bagian dari daerah ini. Berbagai tradisi yang membentu budaya masyarakat Gorontalo tetap dijaga dan dulestarikan hingga saat ini. Karena hal inilah maka Van Vollenhoven, seorang antropolog Belanda menetapkan Gorontalo sebagai satu dari sembilan belas daerah hukum adat di Indonesia (Vollenhoven, 2013: 44). Salah satu tradisi yang tidak bisa dipisahkan dengan masyarakat Gorontalo hingga hari ini adalah tradisi hileyia.

Tradisi hileyia adalah tradisi yang berkaitan dengan tata laksana ritual kematian pada sebagian masyarakat Gorontalo. Secara etimologis kata hileyia berakar pada kosa kata bahasa Gorontalo yakni kata heyi yang berarti pindah.(Pateda, 2001: 85). Bahkan orang meninggal dalam peristilahan bahasa Gorontalo sering disebut dengan : "bo ta loheyi ma'o mondo dunia" (orang yang hanya pindah dari dunia ini ke alam lainnya).

Istilah hileiya berasal dari kata heiya yang artinya menggeser, memindahkan, yakni memindahkan kegiatan rutin sehari-hari seperti memasak ke tempat keluarga yang berduka, sehingga mereka merasa terhibur dan tidak larut dalam musibah yang menimpa mereka. Tradisi ini sama dengan anjuran ta'ziyyah dalam tuntunan agama Islam (Puhi, 2013:73).

Hileiya (memindahkan), yakni merupakan kegiatan tolong menolong secara spontan oleh setiap anggota masyarakat karena dianggap sebagai suatu kewajiban untuk segera dilaksanakan dan turut serta melibatkan diri dalam suatu kegiatan, misalnya bila ada salah satu anggota keluarga yang mengalami musibah seperti meninggal dunia, maka seluruh warga masyarakat sekitarnya datang untuk menghibur keluarga yang sedang mengalami kedukaan. Orang-orang yang datang ke tempat kedukaan disamping menghibur keluarga 
ditinggalkan, juga warga masyarakat secara suka rela membawa makanan ke tempat duka baik dalam bentuk bahan yang belum masak atau yang telah dimasak seperti kue dan lain sebagainya yang meringankan beban anggota keluarga yang sedang berduka (Yunus, 2014: 102).

Bagi masyarakat Kota Gorontalo, hileyia sebagai sebuah budaya keagamaan masyarakat Kota Gorontalo yang telah bertahan lama dan sulit berubah. Tradisi hileyia ini oleh masyarakat Kota Gorontalo dipandang sebagai perwujudan keterhubungan antara orang hidup dan orang yang sudah meninggal. Hubungan yang tercipta melalui perantaraan doa, diyakini sampai karena merujuk kepada beberapa dalil keagamaan yang dipegang oleh masyarakat. Oleh karena itu masyarakat Kota Gorontalo memandang tradisi hileyia adalah pengejawantahan syariat Islam meskipun dilakukan dalam lingkup tradisi Gorontalo.

Di sisi lain, masyarakat Kota Gorontalo juga menyakini bahwa tradisi hileyia adalah sebuah praktik keagamaan yang bercorak tasawuf. Pola keberagamaan masyarakat Islam di Gorontalo pada umumnya sangat dipengaruhi oleh tasawuf khususnya ajaran tarekat khususnya tarekat Qadiriyah yang dicetuskan oleh Syekh Abdul Qadir Jailani. Dalam perspektif tarekat yang diperpegangi oleh masyarakat Islam Kota Gorontalo, diyakini bahwa pelaksanaan hileyia adalah satu bentuk pengawalan terhadap berbagai peristiwa yang dijalani oleh orang meninggal di dalam kuburannya. Pengawalan dengan doa-doa ini diyakini akan meringankan beban yang dipikul oleh orang meninggal di alam kuburnya.

Kepercayaan masyarakat Islam Gorontalo yang bercorak sufistik dalam kaitannya dengan tradisi hileyia antara lain terlihat dari aturan warna pakaian yang digunakan ketika menghadiri acara hileyia. Dari hari pertama kematian sampai sebelum hari ke-40 menggunakan pakaian berwarna putih karena diyakini kain kafan si mayit masih berwarna putih. Pada doa hari ke-40, digunakan baju berwarna biru, karena kain kafan sudah cenderung berwarna kebiruan terkena cairan tubuh si mayit. Pada doa hari ke-100, digunakan baju berwarna hitam karena kondisi mayat di kuburan yang sudah menghitam. Adapun pada peringatan doa arwah hari ke 200 dan ke 300, digunakan baju berwarna coklat, karena diyakini bahwa tubuh jenazah telah melebur menyatu dengan tanah. Inilah makna kembali ke asal sebagaimana yang bisa dipetik dari satu syair sufistik dalam ajaran tarekat Gorontalo yakni huta mohuwalinga ode huta, taluhu mohuwalinga ode taluhu,dupoto mohuwalinga ode dupoto, tulu mohuwalinga ode tulu yang maknanya tanah kembali ke tanah, air kembali ke air, angin kembali ke angin dan api kembali ke api. Segala sesuatu pasti akan kembali ke asalnya. Berdasarkan pada keyakinan ini, maka tradisi hileyia dilaksanakan mengiringi sebuah peristiwa kematian untuk mengawal berbagai proses yang dijalani oleh si mayit di dalam kuburnya. Kata hileyia yang secara umum bermakna pindah, namun secara spesifik terkait dengan adanya kematian pada masyarakat Gorontalo berarti memindahkan dapur atau memindahkan aktivitas di dapur ke rumah kerabat yang sedang berduka.

Aktivitas dapur berupa masak memasak makanan konsumsi rumah tangga adalah aktivitas rutin masyarakat di manapun termasuk di Kota Gorontalo. Namun dalam suasana berduka, aktivitas dapur agak terganggu ritmenya karena orang di rumah semuanya dalam keadaan berduka. Padahal kebutuhan akan makan dan minum adalah kebutuhan primer yang tidak bisa ditolak keadaannya. Dalam konteks inilah berlakulah makna hileyia, memindahkan aktivitas dapur para tetangga dan kerabat ke rumah yang berduka untuk meringankan beban keluarga berduka dari bebanbeban rumah tangga yang selama ini dilakukan oleh keluarga yang berduka.

Meskipun demikian tradisi hileyia pada masyarakat Kota Gorontalo memiliki makna yang lebih luas lagi dan tidak hanya terbatas pada pemindahan aktivitas dapur ke rumah orang berduka. Makna hileyia yang lebih luas lagi yakni bertujuan memberikan hiburan kepada keluarga yang berduka agar senantiasa tidak larut dalam duka. Berkumpulnya para kerabat dalam harihari duka akan sedikit mengurangi rasa duka yang dirasakan keluarga.

Aktivitas berkumpul mulai memasak bersama, mengurus rumah, berdoa bersama-sama, bahkan diselingi dengan permainan-permainan tradisional Gorontalo, akan memberikan suasana yang saling menguatkan antar keluarga dan secara psikologis memberikan penguatan batin kepada keluarga berduka. Dengan demikian tradisi hileyia ini benarbenar meringankan beban keluarga yang berduka baik secara jasmaniah maupun secara ruhaniah.

\section{Motivasi dan Batasan Melaksanakan Hileyia}

Tradisi hileyia memperlihatkan kuatnya ikatan sosial dalam masyarakat Kota Gorontalo 
utamanya dalam situasi di mana ada salah satu anggota masyarakat yang tertimpa musibah kematian. Meskipun demikian terdapat banyak faktor yang memotivasi masyarakat Kota Gorontalo untuk tetap melaksanakan tradisi hileyia ini. Motivasi utama mengapa sebagian besar masyarakat Kota Gorontalo melaksanakan tradisi hileyia adalah keyakinan. Tradisi ini didasari sebuah keyakinan tentang keterhubungan antara orang hidup dan orang yang sudah meninggal. Orang hidup masih bisa membantu orang yang meninggal melalui doadoa yang dipanjatkan dalam majelis hileyia. Ada keyakinan bahwa doa-doa yang dipanjatkan dalam majelis hileyia akan sampai kepada si mayit yang sedang menghadapi ujian di alam kubur.

Dalam masyarakat Kota Gorontalo masih hidup keyakinan tentang hubungan antara orang hidup dan sudah meninggal. Keterhubungan ini diwujudkan dalam doa. Orang hidup mendoakan orang yang sudah meninggal, dan orang yang sudah meninggal benar-benar merasakan manfaat dari doa yang dikirimkan oleh kerabatnya yang masih hidup.

Keyakinan sebagaimana digambarkan dalam ulasan di atas merupakan motivasi mendasar mengapa tradisi hileyia tetap dilaksanakan oleh sebagian masyarakat Kota Gorontalo hingga hari ini. Motivasi ditunjang oleh motivasi-motivasi lainnya yang berkolaborasi mendorong lestarinya tradisi hileyia ini pada masyarakat Kota Gorontalo. Motivasi lain yang mendorong masyarakat Kota Gorontalo untuk senantiasa melaksanakan tradisi hileyia bagi kerabatnya yang meninggal tampaknya lebih bersifat psikologis karena menimbulkan beban mental yang sangat berat apabila hileyia tidak dilaksanakan. Perasaan bersalah ataupun berhutang dari para keluarga terhadap orang meninggal apabila mereka tidak bisa melaksanakan tradisi hileyia ini karena merasa diri mereka tidak bisa membantu si mayit ketika sedang dalam ujian di alam kubur. Oleh karena itu meskipun sangat sederhana, acara hileyia tetap dilaksanakan. Sebab bila tidak, maka kehidupan akan dirasakan benar-benar tidak nyaman dan hal inilah yang dihindari oleh pihak keluarga yang ditimpa musibah kematian.

Memang melaksanakan tradisi hileyia ini sudah pasti menimbulkan biaya yang tidak kecil. Oleh karena kemampuan ekonomi keluarga yang berduka itu bermacam-macam, maka kemasan acara hileyia itu beragam, meskipun sama dalam hal-hal intinya. Masalah pembiayaan hileyia inilah yang kemudian dipermasalahkan oleh pihakpihak yang tidak setuju dengan tradisi hileyia ini, bahkan ada yang cenderung mengharamkannya karena dianggap menambah beban orang yang berduka misalnya mereka harus berhutang untuk melaksanakan hileyia. Meskipun demikian, sesungguhnya hal ini sudah diantisipasi oleh para pemuka adat Gorontalo.

Para tetua adat Gorontalo telah membuat aturan tentang batasan-batasan dalam pelaksanaan tradisi hileyia utamanya dalam masalah pembiayaan kegiatannya. Batasan utama yang dihindari adalah jangan sampai berhutang untuk melaksanakan tradisi hileyia. Untuk menghindari hutang piutang dalam acara hileyia maka peranan keluarga sangat dibutuhkan. Bukan saja keluarga inti orang meninggal tetapi peran keluarga besarnya untuk menunjang tradisi ini. Perkumpulan keluarga akan memungkinkan terselenggaranya acara hileyia ini tanpa harus melaksanakan dengan berhutang. Demikian pula dengan bagaimana acara hileyia ini diselenggarakan, maka itu akan disesuaikan dengan kemampuan keluarga untuk melaksanakannya. Yang terpenting inti acara yakni doa untuk orang meninggal tetap terlaksana. Doa arwah sebagai inti acara hileyia merupakan hal pokok dibanding hal lainnya.

Bagaimanapun juga tujuan utama dilaksanakannya hileyia yakni untuk mendoakan arwah orang yang meninggal agar diampuni dosadosanya, diterima amal ibadahnya, dimudahkan semua urusannya di alam kubur. Hal-hal inilah yang menjadi pokok doa arwah dalam hileyia. Adapun dalam majelis hileyia ini juga disajikan makanan sebagai bagian dari adab bermasyarakat jika mengundang orang ke rumah. Oleh karena itu, soal jenis dan ragam makanannya tidak ditentukan sesuai dengan kemampuan keluarga untuk menyiapkannya. Kecuali untuk makanan-makanan tertentu yang oleh adat Gorontalo harus ada dalam hileyia misalnya nasi kuning, tili aya, lutu, pingge lo watingo dll, di mana hal-hal ini secara nilai sangat murah dan mampu disiapkan oleh orang miskin sekalipun.

\section{Dinamika Perubahan dan Hikmah Tradisi Hileyia}

Tradisi hileyia pada masyarakat Kota Gorontalo ini mungkin tidak pernah berhenti karena secara alamiah akan selalu ada kematian yang terjadi. Berdasarkan kondisi inilah maka tradisi hileyia senantiasa hidup dalam lingkup 
kehidupan orang Gorontalo sejak dulu hingga kini. Meskipun secara substanial sama saja, akan tetapi ada kondisi yang tidak bisa dihindari yang membuat pelaksanaan tradisi hileyia mengalami beberapa perubahan dari waktu ke waktu.

Bentuk-bentuk perubahan itu antara lain berupa:

\section{Tempat pelaksanaan acara hileyia.}

Sebagaimana pernyataan informan di atas bahwa zaman dahulu acara hileyia dilaksanakan di rumah besar keluarga yang disebut bele da'a. Rumah besar ini memang disediakan oleh setiap keluarga untuk pelaksanaan berbagai acara keluarga yang dihadiri oleh banyak orang seperti acara hileyia ini. Untuk kondisi zaman dahulu di mana masih banyak tanah yang luas, masih mudah memperoleh bahan bangunan murah seperti kayu, dan juga semangat gotong royong masyarakat yang memudahkan pembungunan rumah besar ini.

Kondisi seperti ini sudah pasti berbeda dengan saat ini di mana Kota Gorontalo sudah semakin padat penduduk dan perumahannya. Untuk membangun rumah besar juga semakin mahal dan tak terjangkau oleh kebanyakan orang masa kini. Maka saat ini pelaksanaan hileyia bisa di mana saja karena konsep bele da'a sudah hilang dari masyarakat modern saat ini.

\section{Cara perolehan persediaan acara hileyia.}

Pada zaman dahulu, ketika ada kedukaan yang menimpa salah satu warga masyarakat Kota Gorontalo, maka konsep hileyia dalam arti memindahkan dapur atau aktivitas masak-memasak ke rumah berduka benar-benar terlihat dalam bentuk nyata. Para kerabat akan membawa bahan makanan dan peralatan memasak dari rumahnya ke rumah duka. Banyak orang berdatangan sambil bawa beras, ayam, ikan, rempah-rempah, sayuran, kelapa, dan berbagai kebutuhan acara lainnya.

Kondisi seperti ini sudah agak sulit ditemukan di Kota Gorontalo saat ini. Hal ini bukan berarti bahwa masyarakat Kota Gorontalo sudah tidak bisa bergotong royong lagi. Kegotong royongan masyarakat Kota Gorontalo tetap ada, tetapi tidak dengan model seperti masyarakat Gorontalo di masa lalu. Bila dulu hantaran kelengkapan hileyia dalam bentuk barang, maka kini disampaikan dalam bentuk uang. Dalam era yang serba praktis seperti sekarang ini, keluarga yang berduka kadang tidak mau repot dengan urusan dapur dan lebih mengandalkan catering untuk memenuhi kebutuhan makanan. Hal inilah yang menyebabkan sekarang ini hantaran untuk acara hileyia saat ini lebih dalam bentuk amplop yang berisi sejumlah uang.

\section{Cara penyajian makanan.}

Cara menyajikan makanan pada acara hileyia pada masa lalu adalah dengan dihamparkan dalam suatu majelis. Semua makanan yang akan dihidangkan diletakkan di atas pomejawa (kain berwarna putih yang biasa dijadikan alas makanan dalam acara hileyia). Dan kemudian seluruh keluarga dan para tamu undangan duduk mengelilingi makanan sambil berdoa dipimpin oleh seorang imamu, kasisi, atau sarada'a.

Saat ini model seperti di atas tetap dilaksanakan oleh sebagian meski tetap juga ada yang berbeda. Bila tuan rumah menyajikan makanan yang disediakan oleh catering, maka makanan tidak dihamparkan di hadapan majelis tetapi diatur di meja catering. Adapun yang disediakan di majelis hanya makanan dan kelengkapan acara hileyia yakni nasi kuning, tili aya, lutu, polutube, alama, dan taluhu. Semua kelengkapan ini tetap di atur di atas pomejawa. Di sinilah inti acara hileyia yakni doa arwah dilaksanakan. Keseluruhan acara hileyia tergantung pada pelaksanaan doa arwah di majelis ini. Bila doa arwah telah selesai di majelis ini, barulah para tamu undangan disuguhi makanan.

\section{Kegiatan Pelengkap}

Tradisi hileyia dalam masyarakat Kota Gorontalo tidak semata hanya berisi kegiatan doa arwah saja tetapi juga ada kegiatan pelengkap yang berbeda di zaman dulu dan sekarang. Zaman dahulu, sebelum acara inti hileyia dimulai, imam yang mempin doa akan membaca kitab kuning yang berisi ajaran Islam baik itu dari kitab fiqih, tasawuf, nahwu/sharaf dan kitab-kitab lainnya.

Para peneliti sejarah Gorontalo menemukan bahwa perluasan dan pendalaman serta pengajaran Islam tak bisa dilepaskan dari sumber-sumber pengetahuan agama, berupa kitab-kitab utama yang dipelajari dan dikembangkan di Gorontalo. Hal ini dibuktikan oleh Riedel dalam tulisannya tahun 1870 yang berhasil mendaftarkan sekitar 77 kitab Islam klasik yang beredar dan diajarkan di wilayah Gorontalo. Kitab-kitab tersebut antara lain Zuhrat al-Murid (karya Abdus Samad al-Palimbani/kitab tauhid), Bidayat al-Mubtadi'in (karya Ibnu Rusyd/ kitab fiqih), Ihya' 'Ulum al-Din (karya Imam alGhazali/kitab Tazkiyatun-nafs/tasawuf), Kasyf al- 
Kiram (karya Syaikh Muhammad Zain al-Asyi/ kitab fiqih, tasawuf), dan Ushul al-I'tiqadi (karya al-Laaliqa'i/kitab tauhid) (Hasanuddin dan Amin, 2012:29).

Kegiatan pembacaan kitab kuning dalam acara hileyia ini yang tampaknya sudah hilang karena pada saat ini apabila ada kematian pada masyarakat Kota Gorontalo, selain mengadakan acara hileyia, keluarga dan masyarakat menyelenggarakan acara takziyah dengan menghadirkan para penceramah, baik itu yang dilaksanakan setelah shalat Ashar maupun setelah shalat Isya. Selain menggantikan kegiatan pengajian kitab kuning, acara takziyah ini juga dianggap menggantikan permainan tradisional seperti mo'awuta, motanggi, dan motapula. Permainan-permainan seperti ini tampaknya tidak menarik lagi bagi generasi muda masa kini yang lebih sibuk dengan mainan-mainan modern yang hadir saat ini.

Apa yang telah digambarkan di atas memperlihatkan dinamika dalam pelaksanaan tradisi hileyia di Kota Gorontalo dari waktu ke waktu. Dinamika tersebut membawa konsekwensi berupa terjadinya perubahan terhadap beberapa bentuk tata laksana tradisi hileyia. Perubahan-perubahan yang terjadi dalam beberapa aspek tata laksana tradisi hileyia dipengaruhi oleh perubahan sosial pada masyarakat Kota Gorontalo itu sendiri. Meskipun demikian satu hal yang pasti bahwa perubahanperubahan ini secara substansial tidak mengubah inti dari tradisi hileyia yang telah dilaksanakan oleh masyarakat Kota Gorontalo dalam kurun waktu yang lama. Dinamika yang terjadi dalam tradisi hileyia ini juga yang menyebabkan tradisi ini tetap dapat bertahan dalam sistem budaya masyarakat Kota Gorontalo dan menjadi suatu kebutuhan mendasar apabila ada kerabat atau keluarga yang meninggal dunia.

Hikmah yang lahir dari pelaksanaan hileyia sesungguhnya memiliki manfaat tidak saja berakhir pada lingkup keluarga berduka saja tetapi bagi masyarakat Kota Gorontalo secara keseluruhan. Apa yang terkandung di dalam hileyia memiliki manfaat yang sangat besar bagi masyarakat. Hileyia memungkinkan terjadinya kohesi sosial yang kuat di tengah masyarakat Kota Gorontalo yang plural. Kematian yang menimpa salah satu anggota masyarakat, tidak hanya meninggalkan jejak duka yang mendalam tetapi juga semakin merekatkan hubungan sosial antar berbagai kalangan masyarakat Kota Gorontalo. Hileyia pada akhirnya tidak semata hanya ritual yang mengiringi sebuah peristiwa kematian, namun lebih dari itu, tradisi hileyia ini mengiringi kehidupan masyarakat Kota Gorontalo.

\section{Nilai-nilai Dakwah Kultural dalam Tradisi Hileyia.}

Dalam kehidupan masyarakat Kota Gorontalo yang identik dengan budaya religius dan dakwah Islamiyah, maka banyak di antara budaya masyarakat Kota Gorontalo yang berperan sebagai wujud dakwah kultural. Salah satunya adalah tradisi hileyia. Tradisi hileyia adalah suatu tradisi masyarakat Kota Gorontalo yang bersifat masif meskipun tidak dilaksanakan dalam satu waktu secara bersamaan. Terdapat banyak pesan yang dikandung oleh tradisi hileyia sebagai perwujudan dakwah kultural.

Dalam tradisi hileyia, terdapat kaitan dengan nilai-nilai keagamaan berupa:

\section{Amar makruf nahi munkar}

Tradisi hileyia dalam masyarakat Kota Gorontalo mengandung nilai-nilai amar makruf nahi munkar. Amar makruf nahi munkar itu sendiri mengandung makna perintah kepada hal-hal yang bersifat kebajikan dan larangan atau pencegahan terhadap hal-hal yang bersifat kemungkaran.

Tradisi hileyia itu sendiri sesungguhnya memilikinilai-nilaiyangmendorongmanusiakepada kebajikan dan mencegahnya dari kemunkaran. Dalam hileyia seorang Muslim didorong untuk berbuat kebajikan, baik terhadap orang hidup maupun yang sudah meninggal. Terhadap orang yang hidup khususnya terhadap keluarga orang yang meninggal, kebajikan itu dapat diwujudkan dalam berbagai aspek yang memungkinkan orang yang berduka dapat menjalani hari-hari dukanya tanpa terlalu dipusingkan oleh urusan-urusan yang bisa dibebankan kepada orang lain. Dan terhadap orang yang meninggal, maka kebajikan yang utama adalah memberikan bantuan doa atas keselamatannya dalam menjalani hari-hari di alam kubur.

Tradisi hileyia juga mencegah orang dari kemunkaran. Kemunkaran dalam hal ini antara lain terlihat dari sikap tidak peduli, acuh tak acuh terhadap penderitaan orang yang berduka. Juga adalah sebuah kemunkaran bila tidak mendoakan orang yang meninggal dunia. Maka dengan terlibatnya seorang Muslim dalam pelaksanaan hileyia maka sesungguhnya dia telah terhindar dari 
sebuah kemunkaran, baik terhadap keluarga yang tengah berduka maupun kepada orang meninggal itu sendiri.

Uraian di atas memperlihatkan bagaimana tradisi hileyia mengandung nilai-nilai amal makruf nahi munkar. Nilai-nilai inilah yang selalu mendorong orang-orang Islam yang ada di lingkungan keluarga berduka untuk selalu terlibat berkontribusi dalam penyelenggaraan hileyia yang diselenggarakan oleh keluarga yang tengah dilanda musibah kedukaan.

\section{Ta'awun}

Ta'awun secara harafiah berarti tolong menolong dalam hal-hal yang berhubungan dengan kebaikan. Tradisi hileyia pada masyarakat Kota Gorontalo mengandung nilai-nilai ta'awun dalam hal kebajikan.

Dalam Al-Qur'an Allah swt memberikan perintah untuk saling tolong menolong dalam mengerjakankebajikan danketakwaan sertalarangan untuk tolong menolong dalam berbuat dosa dan pelanggaran. Terkait dengan pelaksanaan hileyia, maka tolong menolong yang terjadi di dalamnya dapat digolongkan sebagai tolong menolong dalam melaksanakan kebajikan dan ketakwaan dan bukan dalam hal dosa dan pelanggaran.

Tradisi hileyia memang sarat dengan ta'awun. Momen hileyia ini memperlihatkan keterikatan dan keterhubungan antara anggota masyarakat Kota Gorontalo dalam situasi sulit yang dihadapi oleh salah satu anggota masyarakat. Dalam situasi duka, masyarakat terpanggil untuk membantu tanpa harus diminta. Segala bantuan berdatangan sebagai perwujudan perasaan saling berduka dan saling merasa atas apa yang dirasakan oleh keluarga yang berduka.

Tradisi hileyia adalah impelementasi nyata tentang ajaran ta'awun dalam Islam. Dalam tradisi ini, masyarakat secara nyata bahu membahu menghadirkan bantuan yang mereka mampui untuk meringankan beban orang yang sedang dilanda kedukaan. Dalam masyarakat Kota Gorontalo, realisasi ta'awun ini diwujudkan dalam huyula, ti'ayo, timo'a, duluhu, dembulo atau depito. Tradisi hileyia menjadi kekuatan perekat ikatan sosial masyarakat Kota Gorontalo, utamanya ketika ada anggota masyarakat yang sedang tertimpa kedukaan.

\section{Zikrul Maut}

Tradisi hileyia mengajarkan kepada orang yang hidup untuk senantiasa $z i k r$ al-maut (ingat akan kematian). Islam mengajarkan kepada umatnya untuk memperbanyak ingat kepada kematian. Mengingat mati akan melembutkan hati dan menghancurkan ketamakan terhadap dunia. Karenanya, Rasulullah saw memberikan dorongan untuk banyak mengingatnya.

Denganbanyakmengingat mati, makamanusia akan banyak menahan ambisi-ambisi duniawi yang terkadang bersifat merusak, baik dirinya maupun orang lain. Sebab dengan memperbanyak ingat akan kematian akan memberikan kesadaran sebanyak apapun nikmat dunia yang dimiliki niscaya akan hilang begitu kematian datang.

Tradisi hileyia pada masyarakat Kota Gorontalo akan selalu mendorong orang-orangyang terlibat di dalamnya untuk senantiasa ingat akan kematian. Karena tradisi ini dilaksanakan dalam kaitannya dengan meninggalnya seorang manusia, maka setiap orang yang terlibat dalam acara hileyia pasti akan selalu diingatkan akan kematian, baik secara langsung ataupun tidak. Suatu saat acara hileyia ini akan diselenggarakan untuk mendoakan kematian salah seorang di antara mereka yang hadir dalam majelis hileyia.

\section{Adab / Akhlak yan Baik.}

Tradisi hileyia pada masyarakat Kota Gorontalo juga mengandung nilai-nilai keagamaan yang berkaitan dengan adab atau akhlak yang mulia. Budaya Gorontalo sangat mengunggulkan adab sebagai bagian pokok dari sebuah keberagamaan. Hal ini seperti tampak dalam suatu ungkapan Gorontalo: o'agama o'adabu, agama yito adabu (ada agama ada adab, beragama itu berarti beradab). Dengan memperhatikan isi ungkapan ini maka dapat dipahami bahwa dalam perspektif orang Gorontalo bahwa sesungguhnya orang yang tidak beradab itu tidak beragama atau kurang agamanya. Demikian pula halnya dengan Islam. Agama Islam adalah agama yang sangat menekankan pentingnya adab atau akhlak yang mulia.

Dalam tradisi hileyia itu sendiri dapat dipetik nilai-nilai ajaran yang berkaitan dengan adab yang baik antara lain:

a. Adab makan dalam sebuah majelis

b. Adab yang berkaitan dengan kepatuhan terhadap imam

c. Adab dalam menghargai orang yang lebih tua

d. Adab yang berkaitan dengan penghargaan terhadap undangan

e. Adab yang berkaitan dengan penghargaan terhadap suguhan makanan. 
Uraian di atas memperlihatkan bahwa tradisi hileyia mengandung nilai-nilai atau pesan-pesan yang baik dan mendorong orang yang terlibat di dalamnya ke dalam kebajikan. Nilai-nilai ini tumbuh dan berkembang dalam masyarakat Kota Gorontalo melalui tradisi hileyia yang terus bertahan dari dulu hingga sekarang. Nilai-nilai inilah yang dipandang sebagai wujud dakwah kultural dalam tradisi hileyia pada masyarakat Kota Gorontalo.

\section{Efek Dakwah Kultural Tradisi Hileyia pada Masyarakat Kota Gorontalo.}

Tradisi hileyia pada masyarakat Kota Gorontalo tidak semata menjadi ritual yang mengiringi peristiwa kematian salah satu anggota masyarakat. Lebih dari itu, tradisi hileyia menjadi salah satu medium dakwah kultural yang senantiasa menghantarkan pesan-pesan akan nilai-nilai kebajikan pada masyarakat Kota Gorontalo. Seruanseruan tentang kebajikan yang mengalir melalui pelaksanaan tradisi hileyia pada masyarakat Kota Gorontalo yang berlangsung terus menerus sudah pasti akan memberikan sebuah efek atau pengaruh dalam kehidupan masyarakat.

Tradisi ini mengajarkan suatu sikap peduli antar sesama anggota masyarakat Kota Gorontalo. Secara faktual sesungguhnyatidak semua masyarakat Kota Gorontalo mampu menyelenggarakan seluruh rangkaian acara hileyia. Hal ini antara lain dipengaruhi oleh kemampuan ekonomi tiap-tiap keluarga untuk melaksanakan tradisi hileyia ini. Meskipun demikian, dengan kadar yang berbedabeda, tradisi hileyia ini tetap bisa dilaksanakan oleh keluarga yang berduka.

Fenomena di atas dimungkinkan untuk terjadi karena satu hal yakni tingginya kepedulian sosial antara sesama anggota masyarakat Kota Gorontalo. Dalam kenyataannya, bila ada anggota masyarakat yang meninggal, maka hampir semua anggota masyarakat di sekitarnya untuk bahu membahu menghadirkan bantuan yang dimampuinya agar keluarga yang berduka dapat melaksanakan tradisi hileyia secara layak. Ada rasa bersalah dan juga rasa malu bila tidak ikut berpartisipasi dan keluarga berduka sampai tidak mampu melaksanakan tradisi hileyia. Bahkan bagi anggota masyarakat yang tidak mampu memberikan sesuatu untuk acara ini, maka dia akan membantu dengan tenaganya, mengerjakan apa yang bisa dia kerjakan, demi lancarnya acara hileyia ini.

Tradisi hileyia ini mampu membangkitkan kepedulian terhadap sesama anggota masyarakat
Kota Gorontalo. Hal ini selain karena ikatan sosial masyarakat Kota Gorontalo yang kuat, juga dipengaruhi oleh suasan religius yang tercipta dalam suatu keadaan duka cita. Tradisi hileyia mampu menghadirkan suatu suasana religius yang menimbulkan sebuah kesadaran bahwa setiap manusia atau setiap keluarga akan mengalami kondisi seperti ini. Kesadaran inilah yang akan membangkitkan motivasi membantu sesama sebagai sebuah amal saleh bekal menuju kematian yang setiap saat akan datang menimpa manusia yang hidup.

Kesadaran religius yang didorong oleh tradisi hileyia merupakan efek nyata dari wujud dakwah kultural dalam tradisi hileyia. Kesadaran-kesadaran inilah yang kemudian melahirkan berbagai budaya masyarakat Kota Gorontalo yang berhubungan dengan gotong royong dan interaksi sosial seperti huyula, ti'ayo, dembulo, depito, dan lain sebagainya. Budaya-budaya merupakan sebuah sistem jaminan sosial bagi masyarakat Kota Gorontalo guna mengantisipasi berbagai suasana yang tidak biasa seperti suasana musibah kematian yang menimpa salah satu anggota masyarakat.

Tradisi hileyia terus menerus menebarkan pesan-pesan keagamaan tentang pentingnya membantu sesama anggota masyarakat yang tertimpa musibah. Tradisi hileyia sebagai sebuah tradisi yang terus berulang dalam masyarakat Kota Gorontalo memberikan efek kesadaran tentang kepedulian sosial antar sesama anggota masyarakat. Efek dakwah kultural melalui tradisi hileyia ini akan terus hidup sepanjang masyarakat Kota Gorontalo masih mau mempertahankan dan mempraktikkan tradisi ini dalam kehidupan mereka.

Efek lainnya yang timbul dari dakwah kultural melalui tradisi hileyia adalah keikhlasan dalam beramal. Mendoakan orang yang sudah meninggal serta mengundang orang lain untuk mendoakannya yang disertai dengan suguhan makanan dianggap sebagai sebuah amal ibadah bagi masyarakat Kota Gorontalo. Meskipun dalam keadaan berduka, namun mereka tetap berupaya melakukan amal ibadah tersebut dengan keikhlasan. Melalui amal ibadah ini, mereka pun berharap dapat mengikhlaskan keluarga yang telah berpulang. Faktor keikhlasan menjadi penting dalam suatu amal ibadah karena menentukan diterima atau tidaknya amal ibadah tersebut oleh Allah swt. Hileyia mengajarkan banyak hal tentang keikhlasan. Ikhlas untuk menerima musibah kematian, ikhlas untuk mendoakan kerabat yang meninggal, ikhlas untuk 
berbagi dengan sesama. Keihklasan-keikhlasan ini sesungguhnya sangat dibutuhkan manusia dalam menjalani kehidupannya di dunia ini.

Efek lainnya yang dapat dipetik dari pelaksanaan hileyia adalah terjadinya silaturahim antar keluarga dan dengan masyarakat yang lebih luas lagi. Dalam peristiwa kematian yang disertai dengan pelaksanaan hileyia maka dalam kesempatan ini terjadi pertemuan antara keluarga yang selama ini berjauhan. Demikian halnya dengan para tetangga, baik yang dekat maupun yang jauh. Terjadinya silaturahim antar keluarga memungkinkan untuk merapatkan hubungan kekeluargaan, menyambung silsilah keluarga, saling membantu dalam berbagai hal. Silaturahim dengan para tetangga dan para sahabat semakin merekatkan ikatan sosial sebagai bagian dari anggota masyarakat.

Uraian di atas memperlihatkan beberapa efek yangtimbul dalam masyarakat Kota Gorontaloakibat sentuhan dakwah kultural dalam tradisi hileyia. Tradisi hileyia sesungguhnya bukan satu-satunya faktor yang mendorong lahirnya efek-efek positif ini dalam masyarakat Kota Gorontalo. Bisa jadi banyak faktor sosial lainnya dalam masyarakat Kota Gorontalo yang ikut berperan memberi pengaruh di dalamnya. Meskipun demikian, penelitian ini berasumsi dengan frekuensi pelaksanaan hileyia yang begitu masif dalam masyarakat Kota Gorontalo, maka akan menempatkan tradisi hileyia sebagaai faktor dominan yang membentuk lahirnya berbagai efek sosial yang positif dalam masyarakat Kota Gorontalo.

Tradisi hileyia adalah suatu tradisi masyarakat Kota Gorontalo yang berlangsung setiap hari sepanjang tahun meskipun tergantung pada ada tidaknya peristiwa kematian. Meskipun tidak hanya menetap di suatu tempat saja, namun peristiwa kematian itu senatiasa terjadi setiap hari di berbagai tempat di Kota Gorontalo. Hal ini antara lain bisa dipantau dari berbagai informasi kedukaan yang disebarkan melalui media massa. Dengan demikian dapat diasumsikan bahwa tradisi hileyia berlangsung setiap hari di berbagai tempat di Kota Gorontalo. Tingginya frekuensi serta luasan wilayah kejadian menyebabkan hileyia menjadi suatu ritual yang mentradisi dalam masyarakat Kota Gorontalo. Dan seringnya masyarakat Kota Gorontalo berinteraksi dengan tradisi ini menyebabkan mereka menjadi begitu lekat dengan tradisi hileyia serta mampu menyerap pesan-pesan kebajikan yang terkandung di dalamnya.
Efek-efek sosial yang positif yang lahir dari sentuhan dakwah kultural dalam tradisi hileyia menjadi sebuah modal sosial (social capital) bagi masyarakat Kota Gorontalo untuk dapat menjalani kehidupan sebagai sebuah komunitas masyarakat yang harmonis. Kepedulian sosial, keikhlasan dalam berbagi, rasa persaudaraan yang tinggi adalah beberapa modal sosial yang lahir dari sentuhan dakwah kultural melalui tradisi hileyia. Modalmodal sosial di atas sesungguhnya sangat relevan dalam berperan membangun harmoni kehidupan sosial dalam masyarakat Kota Gorontalo. Meskipun secara faktual Kota Gorontalo itu adalah sebuah wilayah yang plural baik dari segi etnis, agama, dan dalam beberapa faktor sosial lainnya, namun pluralitas ini jarang menimbulkan masalah, karena masyarakat Kota Gorontalo memiliki suatu modal sosial yang lahir melalui sentuhan dakwah kultural dalam tradisi hileyia.

\section{PENUTUP}

Tradisi hileyia dalam masyarakat Kota Gorontalo adalah suatu gambaran keterhubungan antara orang yang hidup dan yang sudah meninggal. Tradisi yang secara harfiah berarti pindah ini ditandai dengan berpindahnya seorang manusia dari dunia ini ke alam kubur karena kematian. Hal ini diikuti dengan berpindahnya para keluarga dan kerabat dalam tempo tertentu ke rumah duka beraktivitas secara bersama-sama yang diisi dengan doa arwah dan aktivitas kehidupan lainnya dengan tujuan untuk menghibur keluarga yang berduka. Tradisi hileyia telah mengalami beberapa perubahan dalam pelaksanaannya, namun tetap bertahan karena mampu menyesuaikan diri dengan dinamika masyarakat namun tidak kehilangan intinya untuk mendoakan orang meninggal dan menghibur keluarga yang berduka. Di samping itu, motivasi masyarakat yang sangat kuat untuk membantu orang meninggal dengan mendoakannya membuat tradisi hileyia tetap eksis dalam masyarakat Kota Gorontalo hingga hari ini.

Tradisi hileyia dalam masyarakat Kota Gorontalo adalah sebuah budaya agama yang memiliki nilai-nilai dakwah kultural. Hal ini diyakini karena tradisi hileyia mengandung pesanpesan kebajikan yang bisa disebar lauskan melalui perantaraan tradisi ini. Adapun nilai-nilai kebajikan yang terkandung dalam tradisi hileyia antara lain amar makruf nahi munkar, ta'awun, zikrul maut, dan adab / akhlak yang baik. Kandungan nilainilai kebajikan ini dipandang sebagai pesan-pesan dakwah yang terus menerus disebarkan dalam 
masyarakat Kota Gorontalo. Dari aspek inilah maka tradisi hileyia menjadi medium dakwah kultural dalam masyarakat Kota Gorontalo.

Dakwah kultural yang disebarluaskan melalui tradisi hileyia memiliki efek positif dalam masyarakat Kota Gorontalo. Efek positif ini antara lain kepedulian sosial, keikhlasan dalam berbagi, serta rasa persaudaraan yang tinggi. Efek sosial ini dipandang sebagai modal sosial (social capital) yang sangat berkontribusi dalam membangun harmoni sosial dalam masyarakat terlebih dalam konteks masyarakat Kota Gorontalo yang plural.

\section{UCAPAN TERIMA KASIH}

Apresiasi dalam bentuk ucapan terima kasih teriring kepada beberapa kalangan yang membantu memberikan data dan informasi, fasilitas, kemudahan administrasi sehingga artikel yang notabene hasil penelitian lapangan di Kota Gorontalo. Apresiasi yang sama penulis haturkan pada pengelola jurnal Al-qalam yang sudi menerima dan memproses artikel ini hingga layak menjadi bagian edisi ini.

\section{DAFTAR PUSTAKA}

Amin, Samsul Munir.2009. Ilmu Dakwah. Jakarta: Amzah.

Arikunto, Suharsimi.2007. Manajemen Penelitian. Jakarta: Rineka Cipta.

Daulima, Farha dalam Mashadi.2017. Hileyia-Relasi Sinkretis Islam dan Budaya Lokal dalam Ritus Upacara Kematian Etnik Gorontalo.Disertasi. Program Doktor Antropologi Sekolah Pasca Sarjana Fisip Unhas Makassar.
Hasanuddin dan Basri Amin.2012. Gorontalo dalam Dinamika Sejarah Masa Kolonial. Yogyakarta: Penerbit Ombak.

Kuntowijoyo.1996. Muslim Tanpa Masjid, Essai-essai Agama, Budaya dan Politik dalam Bingkai Strukturalisme Transendental. Bandung: Mizan.

Moleong, Lexy J.1991. Metode Penelitian Kualitatif. Bandung: PT. Remaja Rosdakarya.

Pateda, Mansoer.2001. Kamus Bahasa GorontaloIndonesia, Jakarta, Balai Pustaka.

Puhi, Ismail.2013. Nilai-nilai Ekonomi Syariah dalam Sistem Adat dan Budaya Masyarakat Gorontalo, dalam Sofyan AP Kau (Editor) Islam dan Tradisi Kearifan Lokal Gorontalo. Gorontalo, Sultan Amai Press.

Ramdani, Rahmat.2016. Dakwah Kultural Masyarakat Lembak Kota Bengkulu. Jurnal Manhaj Vol. 4 No. 2 Tahun 2016 dalam e-Journal. iainbengkulu.ac.id. diakses tanggal 15 April 2017

Siradj, Said Agiel.1999. Islam Kebangsaan Fiqh Demokratik Kaum Santri. Jakarta : Pustaka Ciganjur.

Sulthon, Muhammad.2003. Desain Ilmu Dakwah Kajian Ontologis, Epistemologis dan Aksiologis. Yogyakarta: Pustaka Pelajar.

Van Vollenhoven, Cornelis.2013. Van Vollenhoven on Indonesian Adat Law. Leiden: KITLV.

Yunus, Rasyid. 2014. Nilai-nilai Kearifan Lokal (Local Genius) Sebagai Penguat Karakter Bangsa, Studi Empiris tentang Huyula. Yogyakarta, Deepublisher. 